Bureau of Mines Report of Investigations/1981

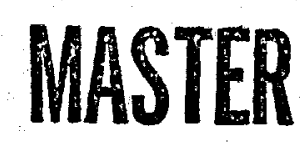

\title{
Corrosion of Materials and Scaling in Low-Salinity East Mesa Geothermal Brines
}

\author{
By F. X. McCawley, S. D. Cramer, W. D. Riley, \\ J. P. Carter, and P. B. Needham, Jr.
}

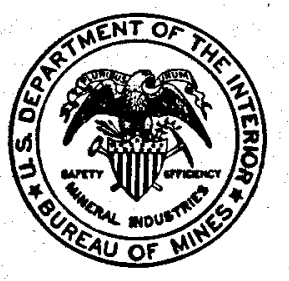

UNITED STATES DEPARTMENT OF THE INTERIOR 


\section{DISCLAIMER}

This report was prepared as an account of work sponsored by an agency of the United States Government. Neither the United States Government nor any agency Thereof, nor any of their employees, makes any warranty, express or implied, or assumes any legal liability or responsibility for the accuracy, completeness, or usefulness of any information, apparatus, product, or process disclosed, or represents that its use would not infringe privately owned rights. Reference herein to any specific commercial product, process, or service by trade name, trademark, manufacturer, or otherwise does not necessarily constitute or imply its endorsement, recommendation, or favoring by the United States Government or any agency thereof. The views and opinions of authors expressed herein do not necessarily state or reflect those of the United States Government or any agency thereof. 


\section{DISCLAIMER}

Portions of this document may be illegible in electronic image products. Images are produced from the best available original document. 
Report of Investigations 8504

Corrosion of Materials and Scaling in Low-Salinity East Mesa Geothermal Brines

By F. X. McCawley, S. D. Cramer, W. D. Riley, J. P. Carter, and P. B. Needham, Jr.

UNITED STATES DEPARTMENT OF THE INTERIOR Cecil D. Andrus, Secretary

BUREAU OF MINES

Lindsay D. Norman, Director 
This publication has been cataloged as follows:

Corrosion of materials and scaling in low-salinity East Mesa geothermal brines.

(Report of investigations ; 8504)

Bibliography: p. 17.

Supt. of Docs. no.: I 28.23:8504.

1. Geothermal engineering-California-Imperial Valley-Equipment and supplies-Corrosion. 2. Geothermal engineering-CaliforniaImperial Valley-Equipment and supplies-Incrustations. I. McCawley, Frank X. II. United States. Bureau of Mines. III. Series: United States. Bureau of Mines. Report of investigations ; 8504.

TN23.U43 [TJ280.7] $622 \mathrm{~s} \quad\left[621.44^{\prime} 028\right] \quad 80-607917$ 


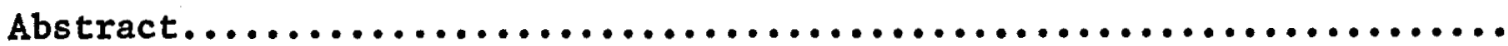

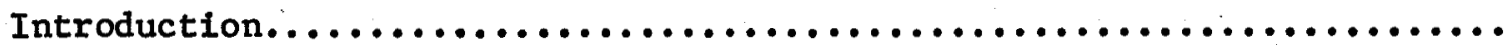

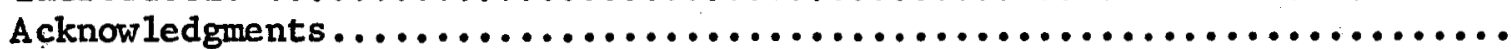

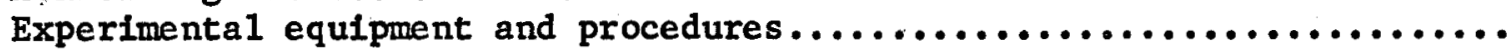

Materials Test Facility.................................

Mobile Chemistry Laboratory ............................

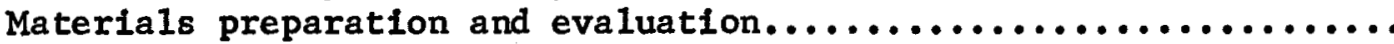

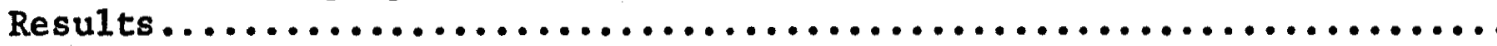

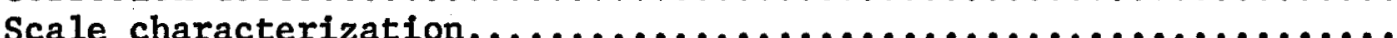

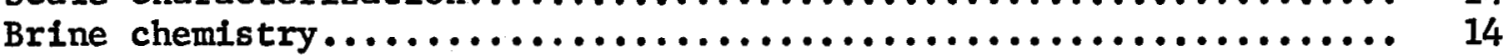

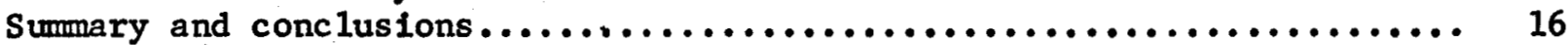

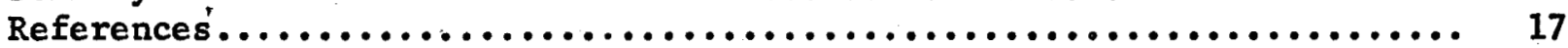

\section{ILLUSTRATIONS}

1. Aerial view of Bureau of Reclamation geothermal test site, East Mesa KGRA, Imperial Valley, Calif......................

2. Bureau of Mines Materials Test Facility (MTF-1) ...............

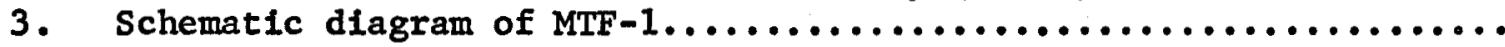

4. Diagram of in situ corrosion test packages....................

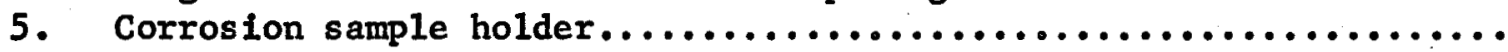

6. Location of sample ports on MTF-1 and wellhead of the geothermal

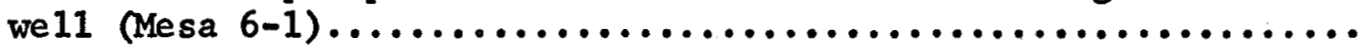

7. Floor diagram of Mobile Chemistry Laboratory....................

8. Carbon steel corrosion samples exposed to five process environments using brine from the geothermal well.......................

9. Type $316 \mathrm{~L}$ stainless steel corrosion samples exposed to five process environments using brine from the geothermal we11........

10. Fluctuations of $\mathrm{pH}$ and several components of the wellhead brine during 22 days of tests, July-August $1975 \ldots \ldots \ldots \ldots \ldots \ldots \ldots \ldots \ldots$

\section{TABLES}

1. Mean operating conditions and composition of process environments in MTF- 1 and at the wellhead during first 7 days of corrosion tests..................................... 7

2. Nominal composition of ferrous alloys used in the corrosion tests..

3. Nominal composition of nickel alloys used in the corrosion tests... 9

4. Nominal composition of titanium and aluminum alloys used in the corrosion tests.....................................

5. General corrosion rates in five process enviroments using Mesa $6-1$ brine, $m i l s$ per year.............................. 


\title{
CORROSION OF MATERIALS AND SCALING IN LOW-SALINITY EAST MESA GEOTHERMAL BRINES
}

\author{
by \\ F. X. McCawley, ' S. D. Cramer, ${ }^{2}$ W. D. Riley, ${ }^{3}$ J. P. Carter, 4 \\ and P. B. Needham, Jr. 5
}

\begin{abstract}
The Bureau of Mines, in pursuing its goal of extending the life span of strategic materials, conducted field corrosion studies at the East Mesa Known Geothermal Resources. Area (KGRA) in the Imperial Valley, Calif., to determine the optimum materials of construction for use in geothermal mineral energy resource recovery plants. These studies included characterization of geothermal environments and in situ corrosion testing. The corrosion resistance of 10 alloys exposed to 5 brine and steam process environments was evaluated using the low-salinity, high-temperature brine from geothermal well Mesa 6-1. of these alloys, Hastelloy C-276, Hastelloy S, Incone1 625, titanium-2nicke1, and $316 \mathrm{~L}$ stainless steel had excellent resistance to corrosion in all of the process enviroments; E-Brite 26-1 and 430 stainless steel had fair resistance. Although general corrosion rates for 4130 steel and 1020 carbon stee 1 were substantially higher than those of the other iron-base alloys, these two alloys could prove useful in low-salinity process environments because of their low cost. Aluminum alloy 5005 was the least corrosion resistant alloy and pitted severely. Scales formed on all of the alloys in every process environment. Calcite, aragonite, and an amorphous silicate were the major components of the scales.
\end{abstract}

\section{INTRODUCTION}

One of the largest 1iquid-dominated hydrothermal resource areas in the United States is the Imperial Valley of California. A number of KGRA's (Known Geothermal Resource Areas), containing substantial quantities of recoverable metals and minerals and energy, are found there. Among these areas is the lowsalinity, high-temperature area located on the East Mesa, known as the East Mesa KGRA. Brines from this area contain minerals at concentrations up to 3 percent total dissolved solids and reach temperatures up to $200^{\circ} \mathrm{C}$. These

${ }^{2}$ Mineral land assessment senior coordinator, Field Operations, Bureau of Mines, Washington, D.C.

a Chemical engineer, Avondale Research Center, Bureau of Mines, Avondale, Md.

3 Physical science technician, Avondale Research Center, Bureau of Mines, Avonda le, Md.

${ }^{4}$ Research chemist, Avondale Research Center, Bureau of Mines, Avondale, Md.

${ }^{5}$ Staff physicist, Minerals Resource Technology, Bureau of Mines, Washington, D.C. 
brines are corrosive and, because of their mineral content, cause scaling of process equipment. In 1974, the Bureau of Mines, began laboratory and field research and testing to characterize and evaluate materials of construction for geothermal mineral and energy resource recovery plants in the Imperial Valley. To meet the objectives of this program, the Avondale Research Center (formerly College Park Metallurgy Research Center) conducted laboratory corrosion research $(\underline{2}, \underline{7}, \underline{9},)^{6}$, thermodynamic studies $(\underline{5}-\underline{6})$, and field corrosion research and tests $(\underline{3}-\underline{4}, \underline{8})$ in geothermal brines. The purpose of the fieldwork was to determine the corrosion-resistant properties of commercially available metals and alloys in geothermal environments, the chemistry of flowing geothermal brines (10), and scale-deposition kinetics (1).

The Bureau's first extensive field test on geothermal materials began in July 1975 at the Mesa 6-1 geothermal well, a low-salinity, high-temperature we11 located on the East Mesa KGRA near Holtville, Calif. Mesa 6-1 is located at the U.S. Department of Energy (DOE) geothermal test site," where desalination studies to produce potable water were being conducted (fig. 1 ). Materials were mounted for evaluation in a Materials Tést Facility (MTF-1) that was connected via pipeline to Mesa 6-1, which is the only well involved in this study. Five process streams typical of those found in a geothermal resource recovery plant were produced in MTF-1. Onsite chemical analyses of the process streams were conducted in a large, we11-equipped Mobile Chemistry Laboratory. MTF-1 was operated from Apr11 through September 1975 to conduct corrosion tests in brine from the well and for brine chemistry studies involvIng Mesa 6-1 and another low-salinity geothermal wel1 nearby, Mesa 6-2 (10). The corrosion tests, originally scheduled for 60 days, were terminated when Mesa 6-1 failed after 22 days of the scheduled 60 day test due to plugging of the well with carbonate scale at a depth of 6,100 feet. This Bureau of Mines report presents corrosion tests conducted in the five brine and steam process streams, the chemical compositions of these streams, and a characterization of the scales and deposits that formed on the corrosion samples.

\footnotetext{
${ }^{6}$ Underlined numbers in parentheses refer to Items in the list of references at the end of this report.

7 Prior to Octover 1, 1977, this facility was part of the Bureau of Reclamation, U.S. Department of the Interior.
} 


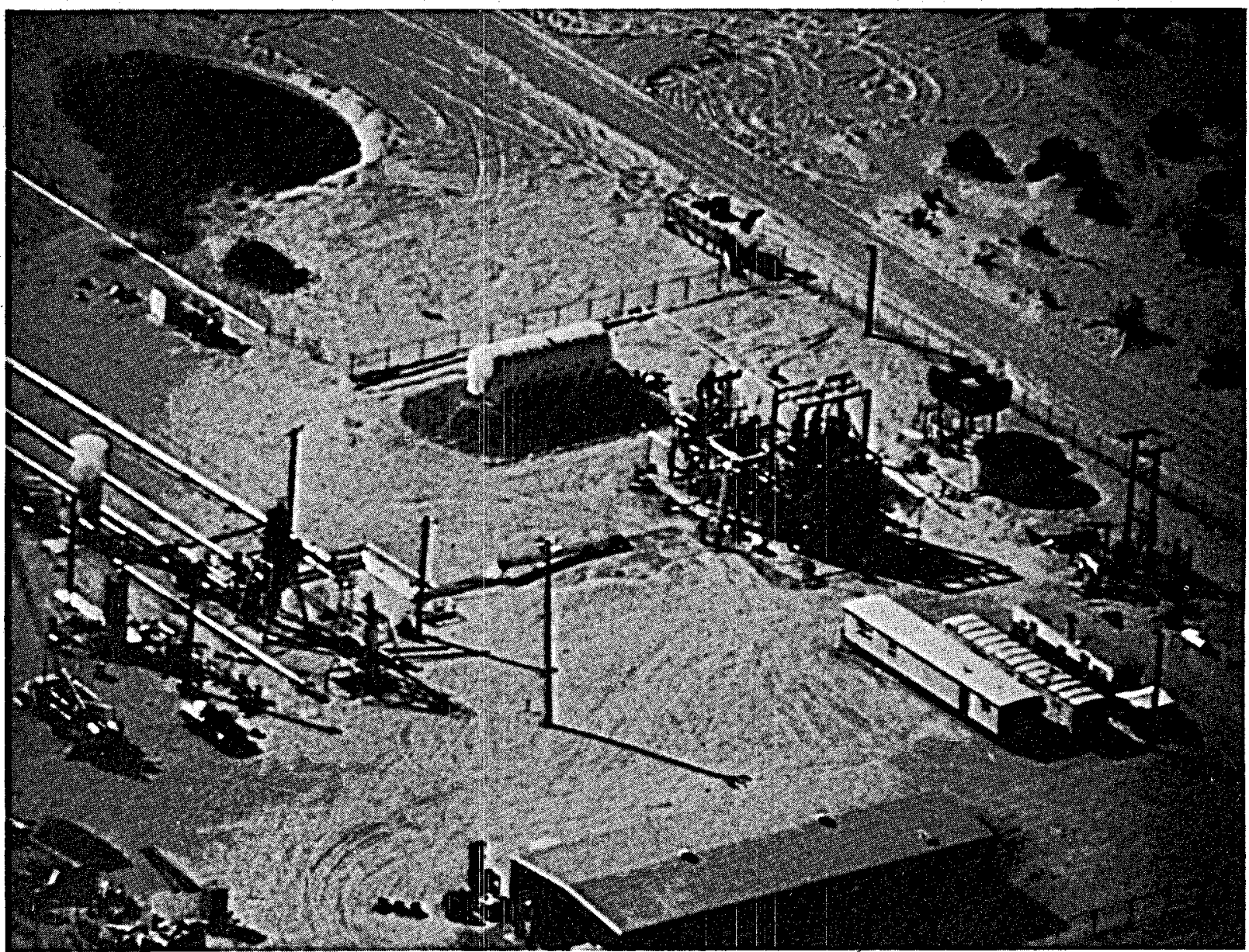

FIGURE 1. - Aerial view of Bureau of Reclamation geothermal test site, East Mesa KGRA, Imperial Valley, Calif.

\section{ACKNOWLEDGMENTS}

The authors express their gratitude for the cooperation and assistance provided by Bureau of Reclamation personnel at their former facilities on the East Mesa KGRA. The knowledge of geothermal process equipment and the welding skills of $U$. Kelly were invaluable in conducting the field tests.

\section{EXPERTMENTAL EQUIPMENT AND PROCEDURES}

\section{Materials Test Facility}

MTF-1 was constructed on a flatbed truck at the Avondale Research Center and moved to the DOE geothermal site on the East Mesa in early 1975. The facility (figs. 2-3) consisted of (1) corrosion test packages for five brine and steam process streams, (2) two steam separators for flashing some of the brine to steam and separating it at elevated pressures, (3) an atmospheric pressure separator, and (4) flow-control valves with their associated pressure control systems. MTF-1 was constructed entirely of 1020 carbon steel. 


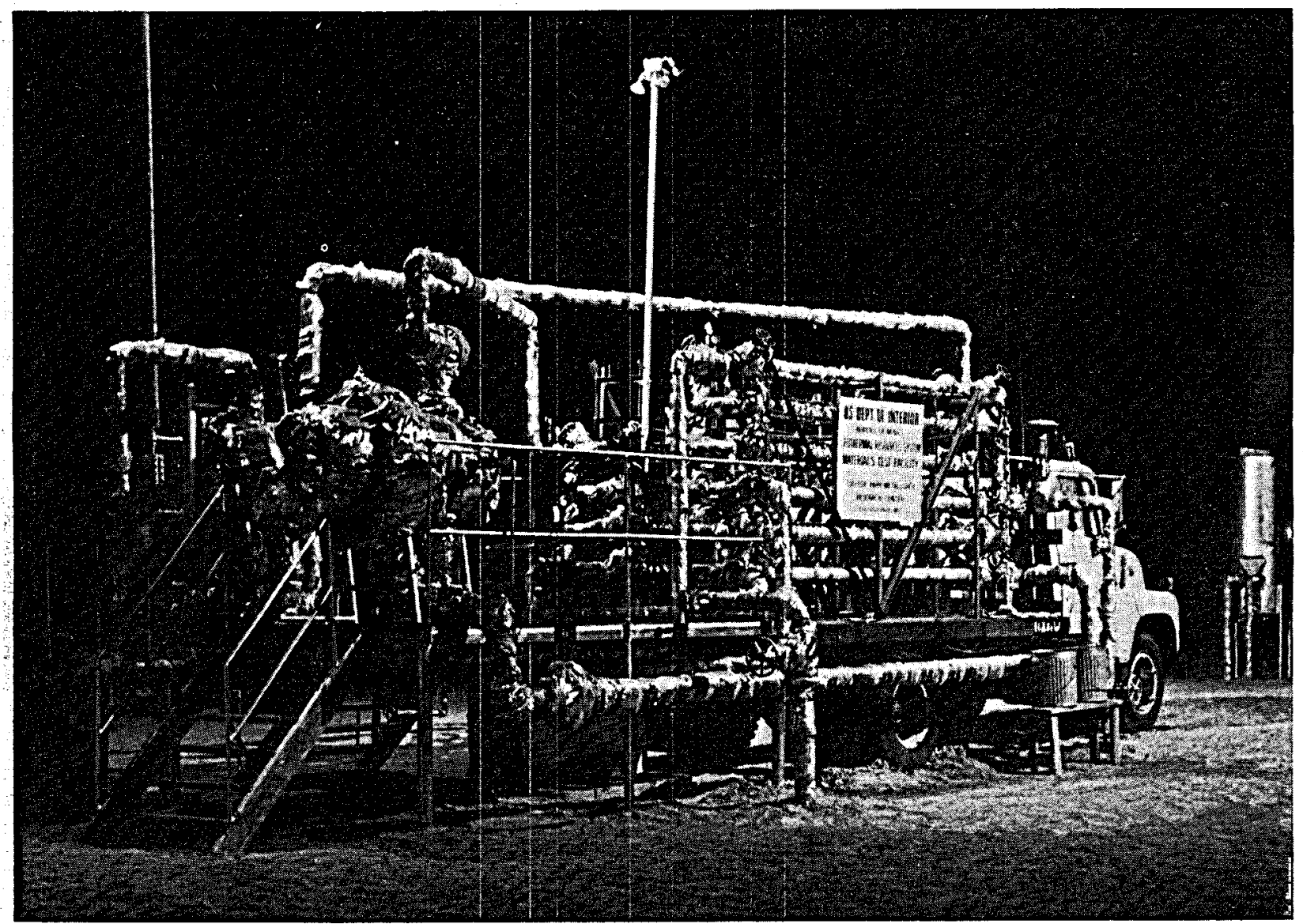

FIGURE 2. - Bureau of Mines Materials Test Facility (MTF-1).

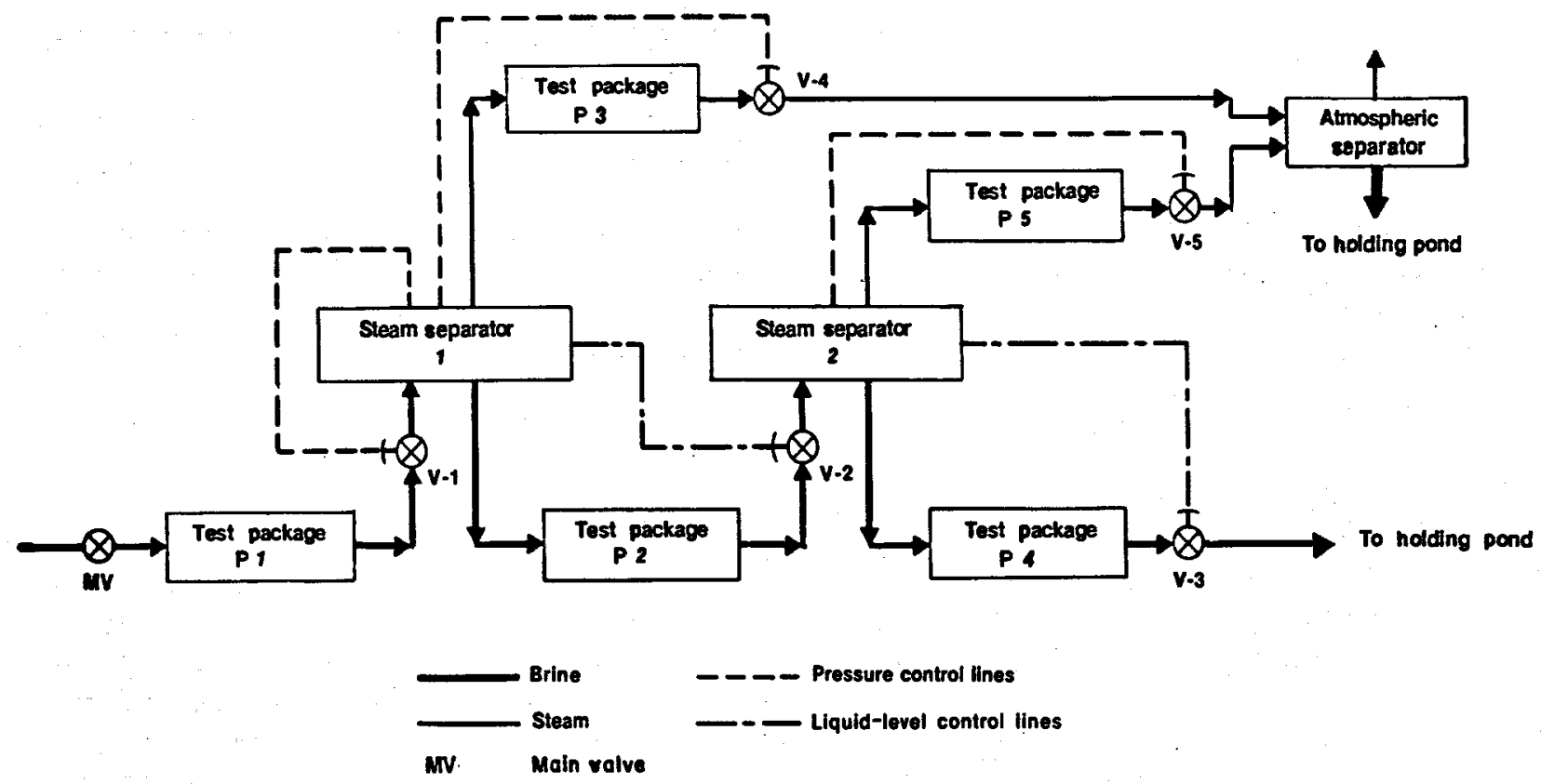

FIGURE 3. - Schematic diagram of MTF-I. 


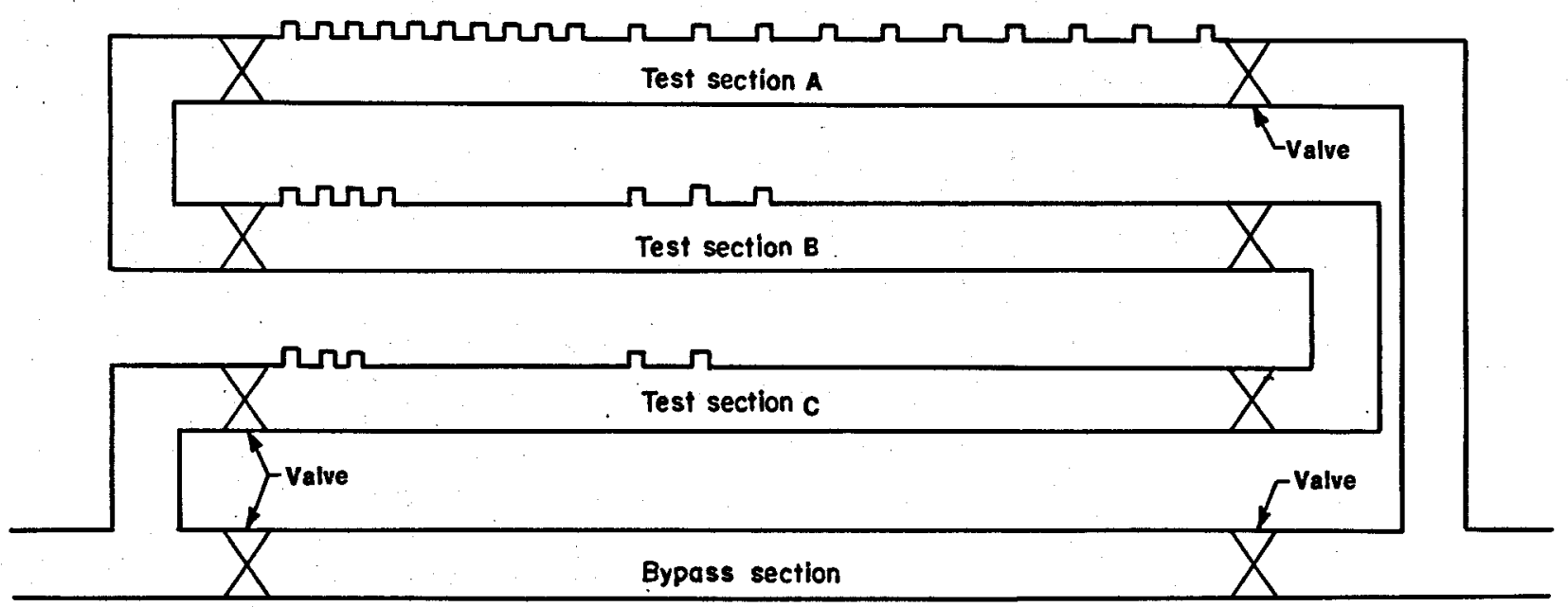

FIGURE 4. - Diagram of in situ corrosion test packages.

Each of the five corrosion test packages (P1 through P5) consisted of three 10-foot-long test sections in which samples were mounted, and a bypass section for routing the brine around the-test sections (fig. 4).

The test sections were constructed from 2- and 3-inch-diameter schedule 80 pipe. Three-inch pipe was used in P1 to transport the wellhead brine, and in P5 to transport the large volumes of low-pressure steam from the secondstage steam separator. Each of the test sections held 20 corrosion samples. Individual sample holders were mounted on vertical ports (approximately 2 inches high) constructed from 2-inch diameter pipe welded at right angles to the test-section pipe ( $f i g .5)$. Ten of the ports were spaced 4 inches apart for mounting samples with their faces normal (at right angles) to the flow of brine or steam (fig. 4). The remaining 10 ports were spaced 8 inches apart for mounting samples with their faces tangential (parallel) to the flow. A 3/8-inch-dlameter rod formed part of each sample holder. The corrosion sample was secured to the rod with a stainless steel screw, and was electrically insulated from the rod and screw by a Teflon gasket and ceramic insulator (fig. 5). Each rod was welded to a 2-inch-dlameter cap and the cap was clamped to the ports during the tests. Teflon or asbestos gaskets were used to seal the sample ports and other flanges on the test sections.

Two steam and two concentrated-brine process streams were produced by the two steam separators. These plus the input brine flowing directly from the wel1 formed the five different enviroments in which the corrosion tests were conducted. The steam separators were 2 feet in diameter by 4 feet long, and were certifled in accordance with the American Society of Mechanical Engineers (ASME) code for pressure vessels to operate at $200 \mathrm{psig}$ at a temperature of $300^{\circ} \mathrm{C}$. Brine entering the separator was projected horizontally towards one end by means of the input pipeline passing vertically through the bottom wall and making a right-angle bend at the centerline. The steam

\footnotetext{
${ }^{8}$ Reference to specific trade names is made for 1dentification only and does not imply endorsement by the Bureau of Mines.
} 


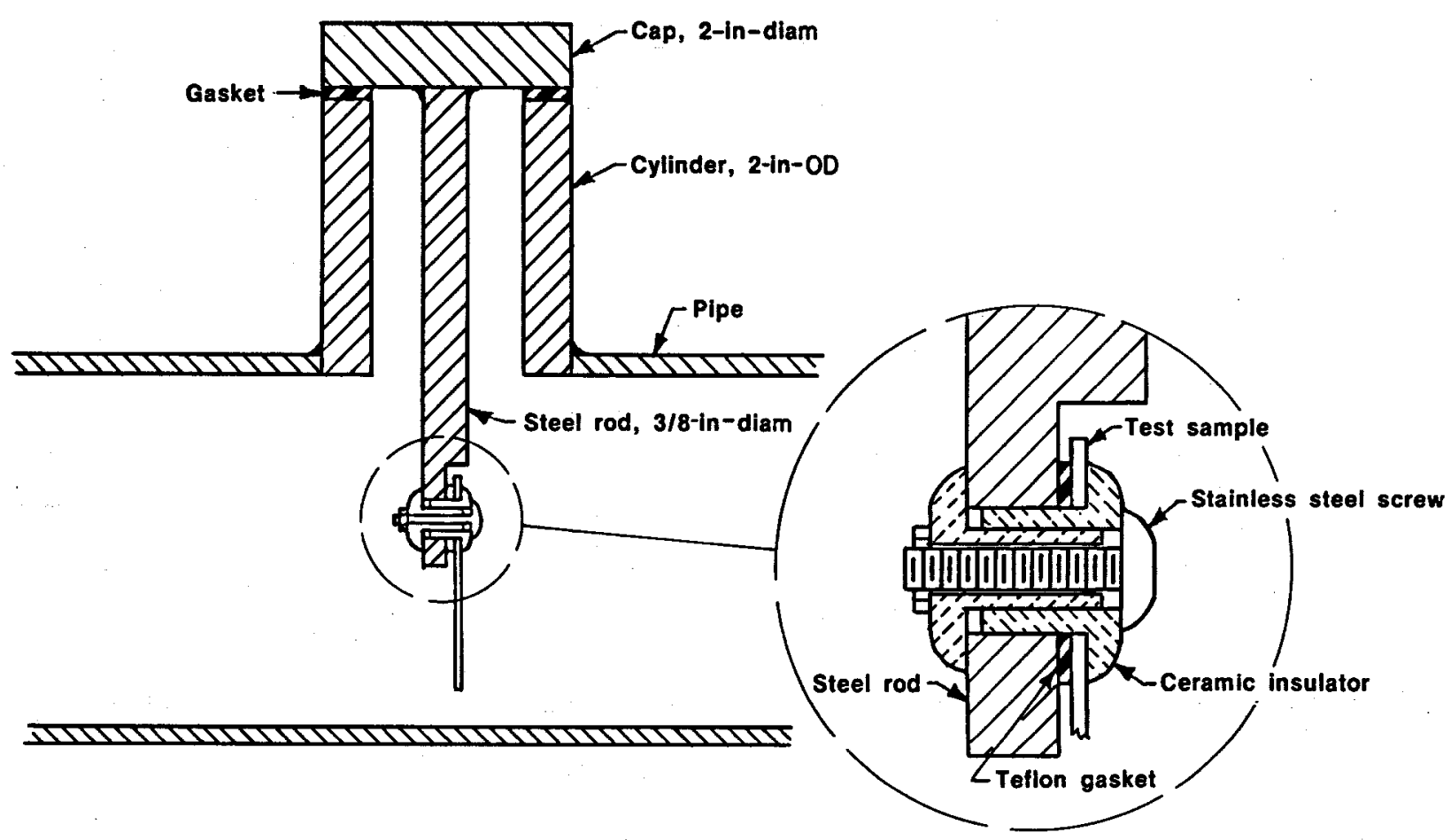

FIGURE 5. - Corrosion sample holder.

separators converted roughly 10 percent of the brine into steam at each stage of flashing. The concentrated brine exited from the bottom of the separators and the steam from the top.

Five pneumatically operated flow-control and pressure-actuated valves controlled the overall operating conditions of MTF-1 (fig. 3); that is, they determined the rate at which brine flowed from the we11, the pressures in each of the test packages, and the amount of steam removed from the brine in each steam separator. Valves $V-1, V-2$, and $V-3$ were flow-control valves; $V-4$ and $V-5$ were pressure actuated. Valves $V-2$ and $V-3$ were controlled by ultrasonic 11quid-level sensors mounted in each of the steam separators.

The average operating conditions for the corrosion test packages are given in table 1. Test package P1 contained input brine that flowed directly from the well at a pressure slightly lower than that of the wellhead owing to viscous losses. Packages P2 and P3 contained brine and steam produced at 85 psig in steam separator 1. Packages P4 and P5 contained brine and steam produced at $50 \mathrm{psig}$ in steam separator 2 from the concentrated brine flowing through package P2. Brine in the steam separators was maintained at a level that provided a brine-mist carryover, producing "dirty" steams; that is, steams containing significant amounts of chlorides. After passing through MTF-1, all 1iquids, including brine and condensate, were discharged into a brine-holding pond. 
TABLE 1. - Mean operating conditions and composition of process environments in MTF -1 and at wellhead during first 7 days of corrosion tests 1

\begin{tabular}{|c|c|c|c|c|c|c|c|c|c|}
\hline \multirow[t]{2}{*}{ Test environment } & \multirow{2}{*}{$\begin{array}{l}\text { Temp, } \\
0 \mathrm{C}\end{array}$} & \multirow{2}{*}{\begin{tabular}{|c|} 
Pressure, \\
psig
\end{tabular}} & \multirow[t]{2}{*}{$\mathrm{pH}$} & \multicolumn{6}{|c|}{ Concentrate, $\mathrm{ppm}$} \\
\hline & & & & $\mathrm{Cl}$ & $\mathrm{Na}$ & $\mathbf{C a}$ & S1 & $\mathrm{K}$ & $\mathrm{Ba}$ \\
\hline $\begin{array}{l}\text { Input brine (P1)....... } \\
\text { 3rine, separator } 1 \text { (P2) } \\
\text { 3rine, separator } 2 \text { (P4) } \\
\text { steam, separator } 1 \text { (P3) } \\
\text { iteam, separator } 2 \text { (P5) }\end{array}$ & $\begin{array}{l}152 \\
152 \\
140 \\
132 \\
140 \\
132 \\
\end{array}$ & $\begin{array}{l}98 \\
96 \\
85 \\
50 \\
85 \\
50\end{array}$ & $\begin{array}{l}5.6 \\
5.2 \\
6.8 \\
8.1 \\
5.2 \\
5.7\end{array}$ & \begin{tabular}{|r}
11,800 \\
11,000 \\
12,062 \\
12,735 \\
$3,000-5,000$ \\
$200-\quad 500$ \\
\end{tabular} & $\begin{array}{r}6,153 \\
5,850 \\
5,867 \\
6,667 \\
2,803 \\
10 \\
\end{array}$ & $\begin{array}{l}771 \\
700 \\
795 \\
850 \\
300 \\
<10\end{array}$ & $\begin{array}{r}129 \\
115 \\
125 \\
135 \\
44 \\
<10 \\
\end{array}$ & $\begin{array}{r}613 \\
613 \\
645 \\
645 \\
323 \\
82 \\
\end{array}$ & $\begin{array}{l}16.8 \\
15.2 \\
15.9 \\
18.8 \\
16.3\end{array}$ \\
\hline
\end{tabular}

1 Flow rate $35 \mathrm{gpm}$.

Special ports were mounted on each test package to collect samples of the brine or steam (as condensate) for analysis (fig. 6). These samples were cooled to ambient temperature by passing them through a water-cooled stainless steel heat exchanger. No effort was made to preserve dissolved gases in the samples.

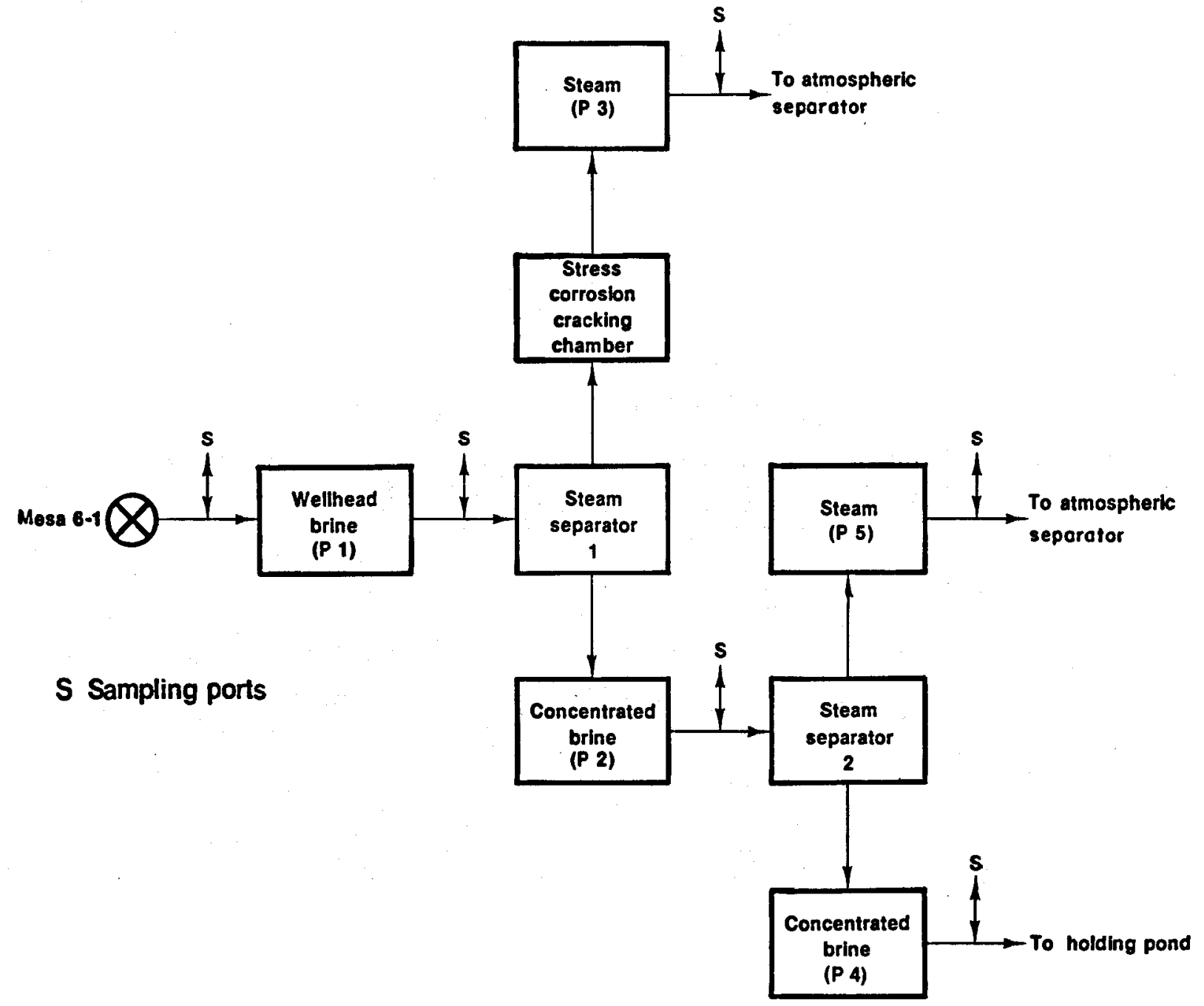

FIGURE 6. - Location of sample ports on MTF:1 and wellhead of the geothermal well (Mesa 6-1). 


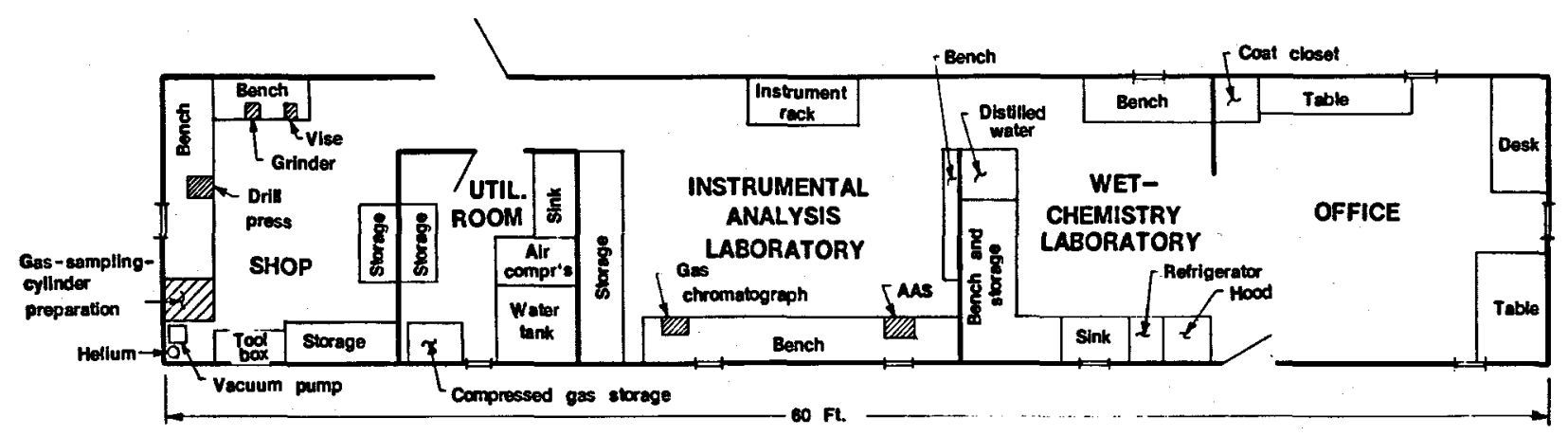

FIGURE. 7. - Floor diagram of Mobile Chemistry Laboratory.

\section{Mobile Chemistry Laboratory}

The Mobile Chemistry Laboratory was a converted mobile-home trailer containing five basic service areas (fig. 7), including instrumental- and wet-chemistry analytical laboratories, an office area, a small machine shop, and a utility room (tap $\mathrm{H}_{2} \mathrm{O}$, distilled $\mathrm{H}_{2} \mathrm{O}$, compressed air, vented-gas storage, and vacuum pumps). The instrumental analysis laboratory was equipped with an atomic absorption spectrophotometer (AAS), gas chromatograph (GC), and a $\mathrm{pH}$-ion meter. The wet-chemistry laboratory was used primarily for carbonate and chloride determinations. The laboratory, used for onsite analyses of geothermal brines and steams, was located at the Bureau of Reclamation geothermal test site on the East Mesa from December 1974 until January 1976, when it was moved to a site at the Salton Sea KGRA.

\section{Materials Preparation and Evaluation}

The 10 commercially avallable alloys used in the corrosion tests and their nominal compositions are given in tables 2-4. These alloys, selected on the basis of laboratory corrosion studies $(\underline{2}, \underline{7})$, were evaluated for their resistance to general, crevice, and pitting corrosion in the five process streams. In addition, a set of stress-corrosion samples was exposed to the steam from steam separator 1 in a chamber connected directly to the separator and through which all the steam to package P3 flowed. 
TABLE 2. - Nominal composition of ferrous alloys used in the corrosion tests, weight-percent ${ }^{1}$

\begin{tabular}{|c|c|c|c|c|c|}
\hline Element & $\begin{array}{l}1020 \\
\text { carbon } \\
\text { stee1 }\end{array}$ & $\begin{array}{l}4130 \\
\text { steel }\end{array}$ & $\begin{array}{c}430 \\
\text { stainless } \\
\text { stee } 1\end{array}$ & $\begin{array}{c}\text { E-Brite } \\
26-1\end{array}$ & $\begin{array}{c}316 \mathrm{~L} \\
\text { stainless } \\
\text { stee } 1\end{array}$ \\
\hline $\begin{array}{l}\text { Carbon........ } \\
\text { Chromium..... } \\
\text { Columbium.... } \\
\text { Copper....... } \\
\text { Manganese.... } \\
\text { Molybdenum... } \\
\text { Nicke1....... } \\
\text { Phosphorus... } \\
\text { Silicon...... } \\
\text { Sulfur....... }\end{array}$ & $\begin{array}{l}0.2 \\
0 \\
0 \\
0 \\
0^{.45} \\
0 \\
.04 \max . \\
.05\end{array}$ & $\begin{array}{l}0.3 \\
.95 \\
0 \\
0 \\
.5 \\
0.12 \\
0 \\
.04 \max . \\
.3 \max . \\
.04 \max .\end{array}$ & $\begin{array}{c}0.12 \\
16-18 \\
0 \\
0 \\
1 \\
0 \\
0 \\
.04 \max . \\
1 \text { max. } \\
.03 \max .\end{array}$ & $\begin{array}{c}0.001 \\
27.6 \\
.1-\quad .2 \\
.02 \\
.02 \\
1.0 \\
.01 \\
.01 \\
.27 \\
.01\end{array}$ & $\begin{array}{c}0.03 \\
16-18 \\
0 \\
0 \\
2 \\
2-3 \\
10-14 \\
1.045 \max . \\
.03 \max .\end{array}$ \\
\hline
\end{tabular}

1 The balance of the composition is Iron.

TABLE 3. - Nominal composition of nickel alloys used in the corrosion tests, weight-percent 1

\begin{tabular}{c|c|c|c}
\hline Element & Haste11oy S & Has te11oy C-276 & Incone1 625 \\
\hline Cobolt........ & 0.61 & 2.5 & 0 \\
Columbium & & & \\
tantalum..... & 0 & 0 & 3.7 \\
Chromium...... & 16.7 & 15.5 & 21.5 \\
Iron......... & 1.8 & 5.5 & 2.5 \\
Manganese..... & 0 & 1.0 & 0 \\
Molybdenum..... & 14.6 & 16 & 9 \\
Tungsten....... & .22 & 3.75 & 0 \\
\hline
\end{tabular}

1 The balance of the composition is nickel.

TABLE 4. - Nominal composition of titanium and aluminum alloys used in the corrosion tests, weight-percent

\begin{tabular}{|c|c|c|}
\hline & Titanium-2 nicke 1 & Aluminum a11oy 5005 \\
\hline Aluminum............ & 0 & Balance \\
\hline Carbon................ & .02 & 0 \\
\hline Chromium............ & 0 & .1 \\
\hline Copper............. & $\mathbf{0}$ & .2 \\
\hline Hydrogen............. & .006 & 0 \\
\hline Iron................ & .03 & .7 \\
\hline Magnesium............ & 0 & $0.5-1.1$ \\
\hline Manganese............ & 0 & .2 \\
\hline Nicke1............. & 1.35 & 0 \\
\hline Nitrogen............ & .005 & 0 \\
\hline oxygen............. & .062 & 0 \\
\hline silicon.......... & 0 & .4 \\
\hline Titanium............. & Balance & 0 \\
\hline Zinc............ & 0 & .25 \\
\hline
\end{tabular}


The flat samples for general, crevice, and pitting corrosion tests measured 1 by 1-1/4 inches and were approximately $1 / 16$ inch thick. They were cut slightly oversize by shearing and then ground to the correct size on an 80-grit wet-belt sander to remove burrs and distorted metal. After grinding, 8 of the 10 alloys were degreased in methanol, washed in distilled water, dried, and weighed. The two remaining alloys, 1020 carbon steel and 4130 steel, were pickled at $60^{\circ} \mathrm{C}$. in 12 volume-percent $\mathrm{H}_{2} \mathrm{SO}_{4}$ containing 2.5 milliters per 1iter of Rhodine 95 inhibitor to remove mill scale, then washed, dried, and weighed. The flat samples were mounted as shown in fig. 5. The stresscorrosion samples were U-bends prepared from flat 1- by 2 -inch samples. The $U$-bend samples were cleaned in the same way as the flat samples. To introduce stress, they were bent approximately $175^{\circ}$ around a 1 -inch-diameter steel mandrel, and the legs were forced into grooves cut 1 inch apart in an alumina plate.

The test program originally called for four 15-day, two 30-day, and one 60-day exposure of corrosion samples. The first 15-day exposure was completed for the five process streams. However, the second 15-day exposure had to be halted on the 7th day when the we11 (Mesa 6-1) failed. The results presented here are those for (1) the first 15-day exposure, (2) the subsequent 7-day exposure (samples from the second 15-day test), and (3) two 22-day originally intended as the 30-day and 60-day tests.

The samples were removed from the test packages, examined, and photographed. The appearance of the carbon steel and $316 \mathrm{~L}$ stainless steel samples after the 22-day exposure to the steam and the brine process streams is shown in figures 8 and 9 , respectively. Scale samples scraped from the corrosion coupons were analyzed using X-ray diffraction and emission spectrography analyses. Tightly adherent scale and corrosion product were chemically removed from the samples by immersion in either inhibited 12 percent sulfuric ac1d (1020 carbon steel, 4130 steel, and aluminum alloy 5005 samples) or 60 percent nitric acid containing, if necessary, a few drops of hydrofluoric acid to facilitate removal (all other samples). The sulfuric and nitric acid cleaning solutions were used at $60^{\circ} \mathrm{C}$. Between successive immersions in the acid cleaning solutions, the samples were vigorously rubbed with a rubber stopper to remove loose scale and corrosion product. The cleaned samples were examined with an optical microscope for localized corrosion such as pits, crevice attack, and stress-corrosion cracking. General corrosion rates were determined from weight-loss data, and the value reported is the average from at least four samples. 


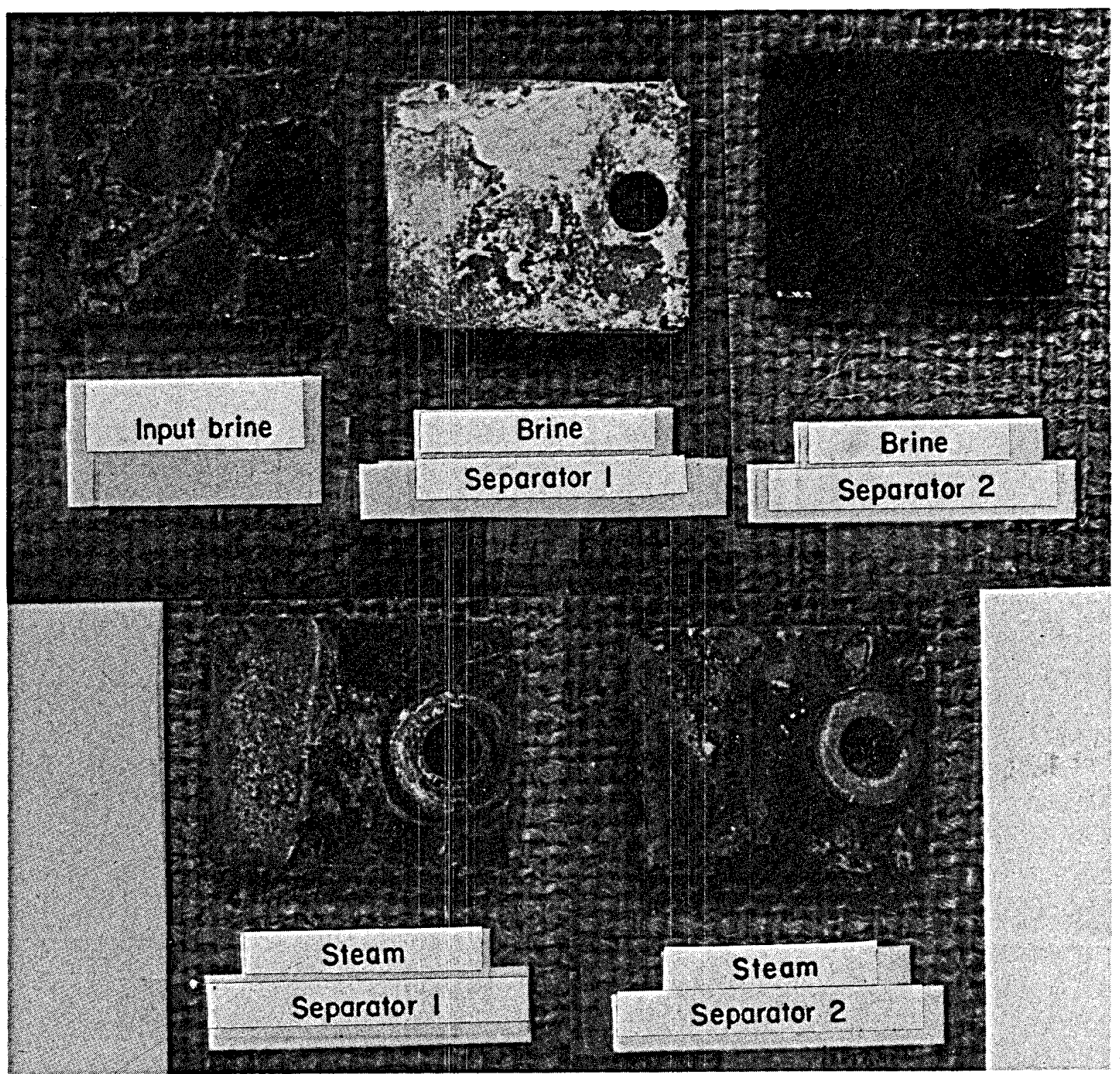

FIGURE 8. - Carbon steel corrosion samples exposed to five process environments using brine from the geothermal well. 

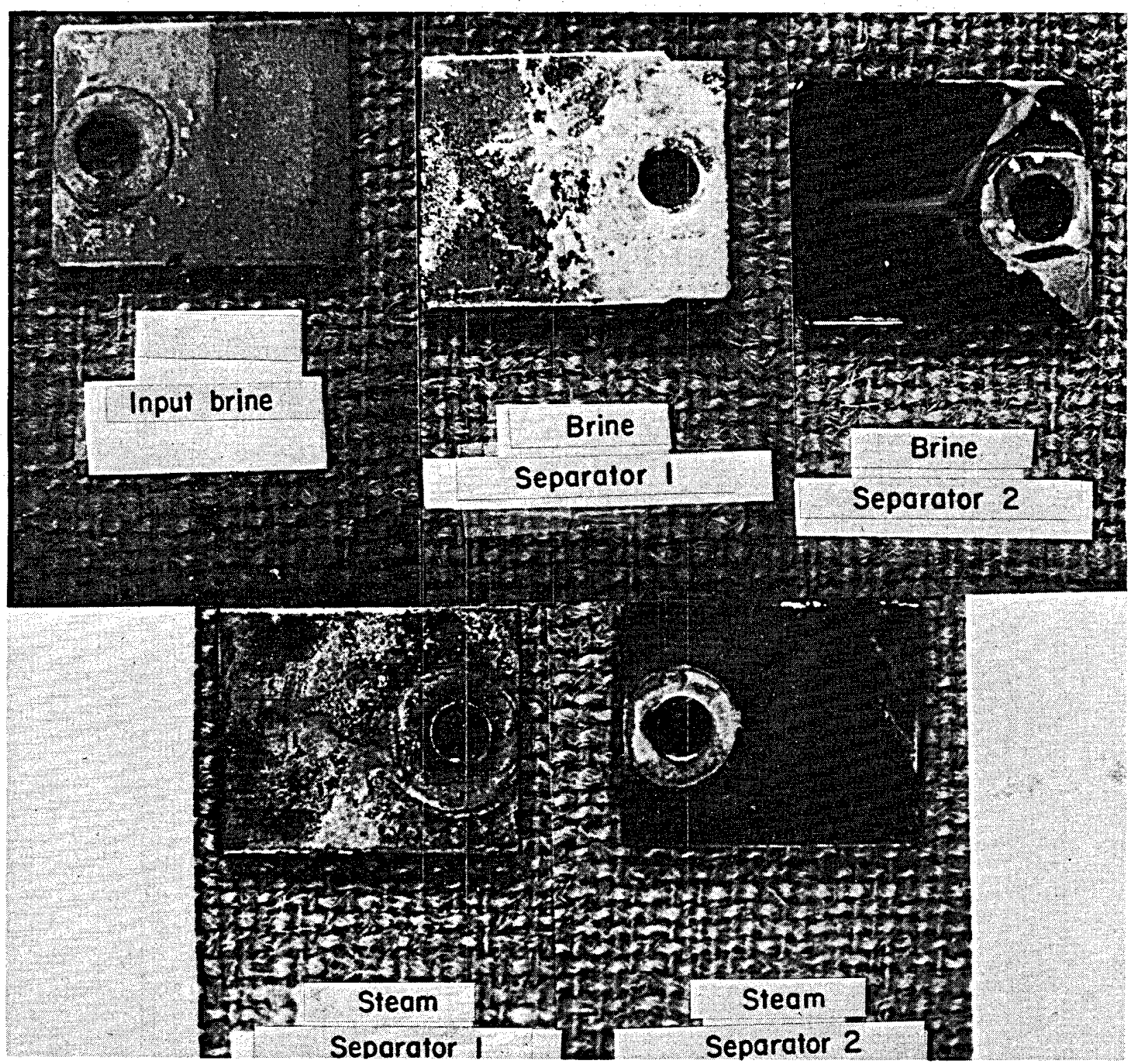

FIGURE 9. - Type $316 \mathrm{~L}$ stainless steel corrosion samples exposed to five process environments using brine from the geothermal well. 
RESULTS

\section{Corrosion Tests}

General corrosion rates are given in table 5 for 1020 stee1, 4130 stee 1 , 430 stee1, 430 stalnless stee1, E-Brite 26-1, and aluminum alloy 5005 exposed to the five brine and steam process streams for exposure perlods of 7,15 , and 22 days. Hastelloy C-276, Hastelloy S, Inconel 625, titanium-2 nickel, and $316 \mathrm{~L}$ stainless steel had excellent resistance to general corrosion in these five enviroments, with corrosion rates less than $0.1 \mathrm{mil}$ per year and, therefore, were not 1 isted in table 5; however, only Hastelloy c-276 exhibited no evidence of corrosion as determined by optical microscopy. For example, $316 \mathrm{~L}$ stainless stee 1 and Incone1 625 were susceptible to localized corrosion in the form of pits too shallow to measure with an optical micrometer, and titanium-2nickel and Hastelloy $S$ exhibited a slight roughening of their surfaces.

\section{TABLE 5. - General corrosion rates ${ }^{1}$ in five process environments} using Mesa $6-1$ brine, mils per year

\begin{tabular}{|c|c|c|c|c|c|c|c|c|c|c|c|c|c|c|c|}
\hline \multirow[b]{2}{*}{ Exposure, days. } & \multicolumn{3}{|c|}{$\begin{array}{l}\text { Input brine } \\
\text { (PI) }\end{array}$} & \multicolumn{3}{|c|}{$\begin{array}{l}\text { Brine, } \\
\text { separator } 1 \\
\text { (P2) }\end{array}$} & \multicolumn{3}{|c|}{\begin{tabular}{|c|} 
Brine, \\
separator 2 \\
(P4)
\end{tabular}} & \multicolumn{3}{|c|}{$\begin{array}{c}\text { Steam, } \\
\text { separator } 1 \\
\text { (P3) }\end{array}$} & \multicolumn{3}{|c|}{\begin{tabular}{|c|} 
Steam \\
separator 2 \\
(P5)
\end{tabular}} \\
\hline & 7 & 15 & 22 & 7 & 15 & 22 & 7 & 15 & 22 & 7 & 15 & 22 & 7 & 15 & 22 \\
\hline & & 3.2 & 2.8 & & 2.4 & 2.1 & 3.4 & 3.4 & 11.2 & & .0 & 4 & 3.2 & .1 & 4.5 \\
\hline $\begin{array}{l}4130 \\
430 \mathrm{~s}\end{array}$ & 10.2 & 1.9 & 2.3 & 1.1 & 1.6 & 2.1 & 2.1 & 1.1 & 1.0 & 15.3 & .3 & L. & 9.2 & 2.5 & 2 \\
\hline & 6. & -1 & 1. & - 0 & .5 & .9 & .2 & .2 & .2 & 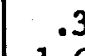 & .0 & 1 & $=$ & .0 & ? \\
\hline $6-1 \ldots$ & 9. & .0 & 2.2 & .3 & .0 & .2 & .2 & .1 & .2 & 1.6 & $: 0$ & .1 & .5 & .1 & .2 \\
\hline & & & & & 1. & & & $?$ & & & ?ח & & & & \\
\hline
\end{tabular}

1 Corrosion rates were less than $0.1 \mathrm{mil}$ per year for $316 \mathrm{~L}$ stainless steel,

Hastelloy S, Hastelloy $\mathrm{C}-276$, Inconel 625, and titanium-2nickel.

$\geqslant$ To convert mils to micrometers, multiply by 25.4 .

E-Brite 26-1 and 430 stainless stee 1 had excellent resistance to corrosion in the separated brine and steam environments (P2 through P5), but had only fair resistance to corrosion in the input brine (P1). Corrosion rates for these alloys In input brine varied widely for the three exposure periods. They were appreciably greater for the 7- and 22-day tests, which began after or continued past the first 15 days of operation, suggesting that a substantial change in brine chemistry occurred during the second exposure period. This change will be discussed in the "Brine Chemistry" section of this report. Microscopic examination of the 430 stainless steel samples showed that shallow pitting, similar to that observed on the $316 \mathrm{~L}$ stainless steel samples, occurred in all five environments. Shallow pitting was also observed on E-Brite 26-1 samples exposed to input brine and to concentrated brine from steam separator 1. There was no evidence of corrosion on E-Brite 26-1 samples exposed to the steam environments and to the concentrated brine from steam separator 2 .

Both 1020 carbon steel and 4130 steel had fair resistance to general corrosion in the five enviroments. These steels showed no evidence of pitting or crevice corrosion attack when examined by optical microscopy. 
Aluminum alloy 5005 had poor resistance to general corrosion in the input brine and in the brine and steam from separator 1 , and the corrosion resistance was only fair in the brine and steam from separator 2. In addition to high general corrosion rates in packages $\mathrm{P} 1$ through $\mathrm{P} 3$, the aluminum alloy 5005 samples were severely pitted and showed a high susceptibility to crevice corrosion.

General corrosion rates for the 10 alloys were not affected by sample orientation (normal or tangential) in the flow of brine or steam.

None of the U-bend samples exposed for 22 days in the steam from separator 1 showed evidence of stress corrosion cracking when examined by optical microscopy. Furthermore, no cracks were exposed when the legs of the U-bend samples were compressed together.

\section{Scale Characterization}

Scaling occurred on test samples exposed in each of the five process streams. The major crystalline phases in the scales were identified by X-ray diffraction as aragonite and calcite. These crystalline components were accompanied by substantial amounts of amorphous material. The composition of the scale formed, on the alloys, with the exception of aluminum alloy 5005 was shown by emission spectroscopic analysis to depend on the process environment. Scale formed in input brine and in the steam and concentrated brine from separator 1 had calcium as the major constituent, iron as a secondary constituent, and minor amounts of $\mathrm{Al}, \mathrm{Ba}, \mathrm{K}, \mathrm{Mn}, \mathrm{Na}, \mathrm{Pb}, \mathrm{Si}$ and $\mathrm{Sr}$. In addition, zinc was detected in trace amounts in the scale formed in the concentrated brine from separator 1 . Scales formed in the steam and concentrated brine from separator 2 had silicon as the major constituent, iron and calcium as secondary constituents, and minor amounts of $\mathrm{A} 1, \mathrm{Ba}$, $\mathrm{Mn}$, Mo, $\mathrm{Na}, \mathrm{Pb}$, and $\mathrm{Zn}$. The scales formed on aluminum samples in the five process environments contained aluminum as the major constituent, with all other elements present in minor or trace amounts.

\section{Brine Chemistry}

The well had been flowing continuously for 3 weeks at an average input brine flow rate of 115 gallons per minute prior to the corrosion tests. During the tests, the flow rate of the well was 35 gallons per minute. Fluid samples were taken for chloride, $\mathrm{pH}$, and carbonate determinations at 4-hour intervals from ports located on MTF-1 at positions labeled "s". in figure 6 . Samples for atomic absorption spectroscopy and gas chromatography were obtained at 8-hour intervals.

A major portion of the dissolved carbon dioxide was removed in separator 1. The loss of the carbon dioxide substantially increased the $\mathrm{pH}$ of the separated brine. The higher $\mathrm{pH}$ of the brine from separator 2 (table 1 ) indicates that additional carbon dioxide was removed from the brine in the second steam separation. 
Variations in the concentration of several components of the input brine over the 22 days of the tests are 1llustrated in figure 10 . The operating conditions and chemical composition of the environments in each of the five corrosion test packages were stable within \pm 10 percent for the first 7 days. Mean values for these variables are given in table 1 . On the eighth
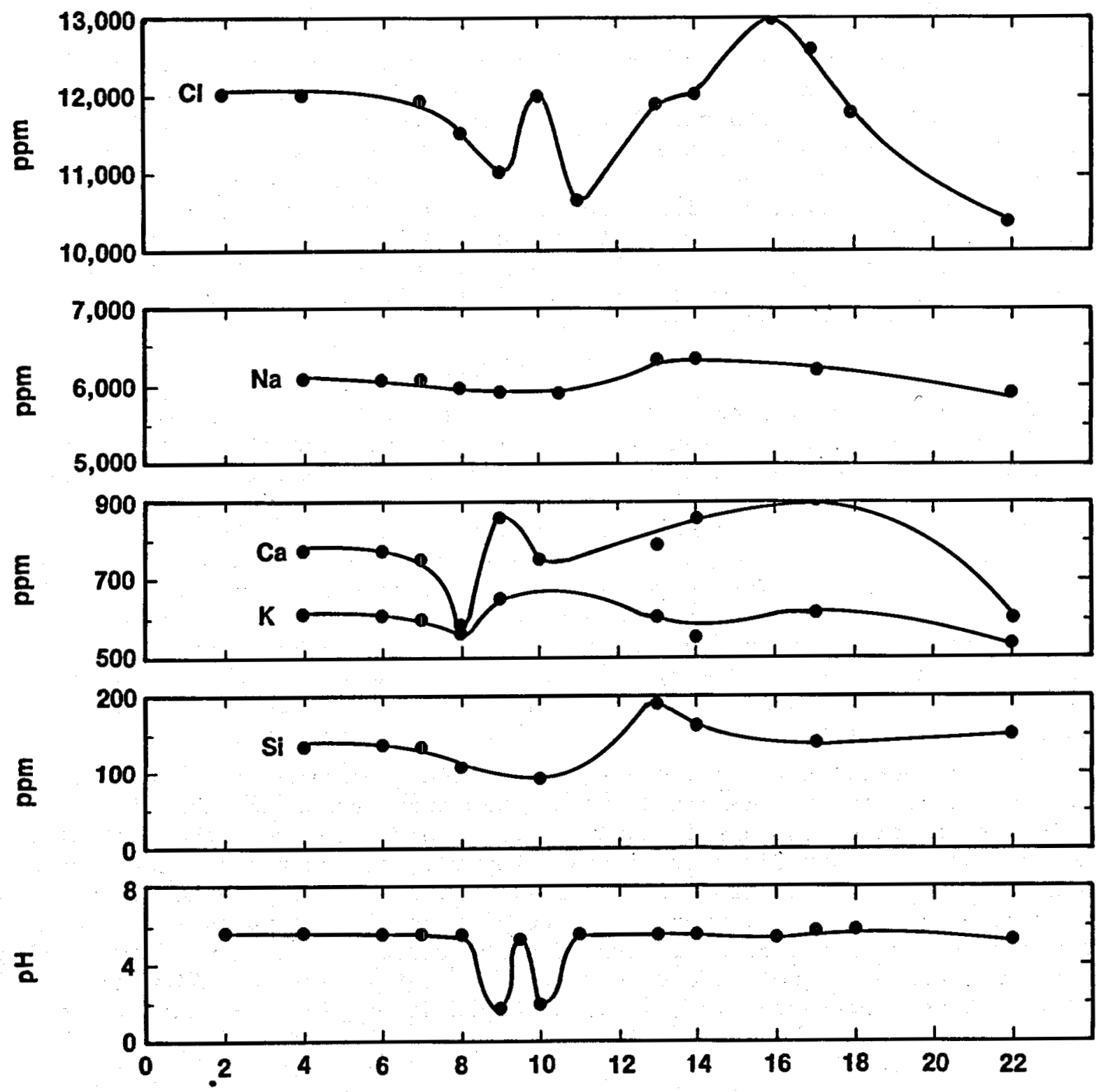

CORROSION TEST TIME, days

FIGURE 10. - Fluctuations of $\mathrm{pH}$ and several components of the wellhead brine during 22 days of tests, July-August 1975. 
day, a ground tremor resulted in changes in the input-brine composition.9 Because these changes persisted, a stable input-brine composition was not reestablished during the remainder of the tests from the 8th through the $22 \mathrm{~d}$ day. Variations occurred in the concentrations of a11 major dissolved species, but calcium and chlorine were affected the most. Similar variations occurred in the composition of the fluids forming each of the process environments.

Corrosion rates for most materials were higher for the 7-day exposure coming near the end of the 22-day test period. This increase apparently reflected the chemical changes that had occurred in the brine after the ground tremor. Corrosion rates for materials exposed 22 days were also higher than rates observed in the initial 15-day test. However, the increase was less than that for materials exposed 7 days, probably owing to the buildup of scale on samples prior to the change in brine composition. Flow from the well ceased on the 22d day of the scheduled 60-day test. Subsequent redrilling of the well removed a large plug of carbonate scale that had formed 6,100 feet below the surface.

\section{SUMMARY AND CONCLUSIONS}

Although the corrosion tests conducted at the East Mesa KGRA lasted only 22 days owing to plugging of the we11, data were obtained on the performances of some commercially available alloys in low-salinity geotherma 1 brines. These data are essential in the selection of materials of construction for geothermal resource recovery facilities. Onsite monitoring was useful for promptly detecting changes in the composition of the geothermal enviroments. Variations in the corrosion rates for different exposure periods seemed to correlate with changes in the chemistry of the input brine. For example, corrosion rates for E-Brite 26-1 and 430 stainless steel in the 7- and 22-day exposures were generally higher than those for the 15-day test, reflecting chemical changes that occurred in the input brine after the ground tremor on the eighth day of the test.

In the low-salinity, near-neutral chloride geothermal environments, ferritic steels such as E-Brite $26-1$ and 430 stainless steel were less resistant to corrosion, particularly pitting corrosion, than the austenitic steels and nickel and titanium alloys. However, all of these alloys appear suitable for use as construction materials in low-salinity geothermal environments. The 1020 carbon steel and 4130 steel also appear useful as construction materials since their corrosion rates were not excessively high in the process environments and they are low-cost materials. Aluminum alloy 5005 does not appear suitáble for applications in low-salinity geothermal environments because of its low resistance to general, pitting, and crevice corrosion.

These tests were of short duration. Longer tests involving a more thorough examination of stress-corrosion cracking are recomended.

In the opinion of Bureau of Reclamation personne1, the tremor opened a "zone of lost circulation" that released drilling muds and acids into the we11. 


\section{REFERENCES}

1. Barnes, H. L., W. F. Downs, J. P. Rimstidt, and D. 0. Hayba . Control of Silica Deposition in Geothermal Systems. Ann. Rep. on BuMines Grant G0-155140-1, July 1977, PP. 42; available for consultation at Bureau of Mines Avondale Research Center, Avondale; Md.

2. Carter, J. P., and S. D. Cramer. Corrosion Resistance of Some Commercially Avallable Metals and Alloys in Geothermal Brines. Ch. In Corrosion Problems in Energy Conversion and Generation, ed. by C. S. Tedmon, Jr., Trans. Electrochem. Soc., 1974, p. 240.

3. Carter, J. P., and F. X. McCawley, In Situ Corrosion Tests in the Salton Sea Geothermal Brine Environments, J. Metals, v. 30, March 1978 , p. 11 .

4. Carter, J. P., F. X. McCawley, S. D. Cramer, and P. B. Needham, Jr. Corrosion Studies in Brines of the Salton Sea Geothermal Field. BuMines RI 8350, 1979, 35 pp.

5. Cramer, S. D. A Simplified Equation for Calculating the Density of Vapor Saturated Sodium Chloride Brines. Geothermal Energy, v. 6, No. 7, 1978, PP. 22-24.

6. The Solubility of Oxygen in Brines From $0^{\circ}$ to $300^{\circ} \mathrm{C}$. I\&EC Process Design and Dev., v. 19, No. 2, April 1980, pp. 300-305.

7. Cramer, S. D., and J. P. Carter. Laboratory Corrosion Studies in Lowand High-Salinity Geobrines of the Imperial Valley, Callf. BuMines RI $8415,1980,30$ pp.

8. Cramer, S. D., and P. B. Needham, Jr. Linear Polarization Measurements at High Temperatures in Hypersaline Geothermal Brines. BuMines RI $8308,1978,15 \mathrm{pp}$.

9. Needham, P. B., Jr., S. D. Cramer, J. P. Carter, and F. X. McCawley. Corrosion Studies in High Temperature Hypersaline Geothermal Brines. Paper 59 in Corrosion/79, National Association of Corrosion Engineers, Houston, Tex., March 1979, 16 pp.

10. Needham, P. B., Jr., W. D. Riley, G, Conner, and A. P. Murphy. Chemical Analyses for Four Imperlal Valley Geothermal Wells. J. Petro1. Eng., v. 32, No. 4, pp. 105-112, Apri1 1980. 